\title{
Effectiveness of Pineapple Extract (Ananas comosus (L.)) on Streptococcus Pneumococcus Growth
}

\author{
Sri Ujiani \\ Department of Health Analyst, Health Polytechnic of Tanjungkarang, Lampung, Indonesia
}

Email address:

sriujiani123@yahoo.com

\section{To cite this article:}

Sri Ujiani. Effectiveness of Pineapple Extract (Ananas comosus (L.)) on Streptococcus Pneumococcus Growth. American Journal of Health Research. Vol. 9, No. 4, 2021, pp. 107-111. doi: 10.11648/j.ajhr.20210904.12

Received: June 14, 2021; Accepted: June 24, 2021; Published: July 10, 2021

\begin{abstract}
Pneumonia accounts for $15 \%$ of all deaths of children under 5 years of age, and causes death to 808,694 children in 2017. Based on the results of the Basic Health Research (Riskesdas) 2007, shows that the national prevalence of URI: 25.5\%, pneumonia morbidity in infants: $2.2 \%$, underfives: $3 \%, 23.8 \%$ of infant mortality, and $15.5 \%$ under fives. The use of traditional medicine is a treatment that has been carried out from generation to generation and is part of the history of human culture. One of the natural ingredients that can be used as traditional medicine is pineapple (Ananas comosus (L)). Research on the effectiveness of pineapple extract has been conducted Ananas comosus (L.)) on the growth of Streptococcus pneumonia. This type of research is a pure laboratory experimental study in vitro. In this study, the inhibition and killing power of pineapple extract (Ananas comosus (L.)) against the growth of Streptococcus pneumonia at various concentrations of $0.5 \%$; 1\%; 2\%; 4\%; $8 \% ; 10 \% ; 20 \% ; 30 \% ; 40 \% ; 50 \% ; 60 \% ; 70 \% ; 80 \% ; 90 \% ; 100 \%$. This research was conducted at the Lampung Province Health Laboratory Center which was carried out from June to November 2018. The results of the One-way Anova test analysis obtained a $p$-value $=0,000$ so that the $p$-value $<0.05$, which means that The concentration of pineapple extract tested had an effect on the growth of bacteria Streptococcus pneumococcus and the results of the Least Significance Different (LSD) or Post hoc LSD $(p$-value $<0.05)$ showed that pineapple extract was effective in inhibiting and killing Streptococcus pneumococcus at a concentration of $8 \%$.
\end{abstract}

Keywords: Effectiveness, Pineapple Extract, Streptococcus Pneumococcus

\section{Introduction}

Streptococcus pneumoniae (also known as pneumococcus) is a gram-positive, extracellular, opportunistic pathogen that attacks the mucosal surface of the upper respiratory tract of humans [14]. Streptococcus pneumoniae is a bacterium with more than 90 serotypes of the agent most common cause of pneumonia, in addition, comorbid factors such as heart failure, kidney disease, and lung disease may increase the risk of pneumococcal pneumonia [4].

Pneumonia, which is a type of URI is a type of pneumonia, which is also the cause of high morbidity and mortality worldwide, caused by bacteria, viruses, fungi, or other microorganisms [4]. URI itself is basically the main cause of morbidity and mortality of infectious diseases in the world and is one of the main causes of consultation or hospitalization in health care facilities [12].

According to WHO, Pneumonia accounts for $15 \%$ of all deaths of children under 5 years of age, and causes death to 808,694 children in 2017. Whereas in Indonesia itself, based on the results of the Basic Health Research (Riskesdas) in 2007, it shows that the national prevalence of URI: $25.5 \%$ (16 provinces above the national rate), pneumonia morbidity in infants: $2.2 \%$, toddlers: $3 \mathrm{t} \%$, the mortality rate (mortality) in infants is $23.8 \%$, and under fives $15.5 \%$ [1]. In 2017 , WHO listed $S$. pneumoniae as one of the 12 priority pathogens [14].

Pneumonia can cause death if not treated immediately. Treatment of pneumonia consists of antibiotics and supportive medication. Antibiotics should be based on the causative microorganism and the sensitivity test results. And the pattern of sensitivity of bacteria to antibiotics tends to change with the use of antibiotics itself. One of the things that is worrying recently is the increasing resistance of bacteria that cause URI to several antibiotics. Many antibiotics are no longer effective for treatment because of bacterial resistance that arises from the use of antibiotics that 
are not correct and inappropriate [5].

The high prevalence of Upper Respiratory Tract Infections (URI) and its effects can result in high consumption of overthe-counter drugs (such as anti-influenza, cough medicines, multivitamins) and antibiotics. In fact, many antibiotics are prescribed to treat this infection. Excessive administration of antibiotics often occurs in patients with respiratory infections, especially acute upper respiratory tract infections, although most of the causes of this disease are viruses. One of the causes is the excessive expectation of clinicians on antibiotics, especially to prevent secondary infections caused by bacteria, which actually cannot be prevented. The impact of all of this is an increase in bacterial resistance as well as an increase in unwanted side effects. The high disease burden and increasing resistance to penicillin and other antibiotics have renewed interest in prevention [14].

Pineapple (Ananas comosus (L.)) is native to Central and South America, and is also grown in several tropical and subtropical countries including Hawaii, India, China, Kenya, South Africa, Malaysia, Philippines and Thailand which contain Bromelain [13]. Bromelain is a crude extract of pineapple (Ananas comosus (L)) which contains a mixture of proteolytic enzymes and non-enzymatic substances, so it is widely used as traditional medicine by many indigenous cultures such as the Philippines, Hawaii, etc. It is even widely used as a traditional medicine for several diseases, several research studies have shown the beneficial effects of bromelain in various health-related conditions [9].

Bromelain can be obtained from crude extracts of pineapple (Ananas comosus) which has therapeutic properties on cell growth, malignant, thrombus formation, inflammation, control of diarrhea, dermatological and skin debridement. Bromelain also contains peroxidase, acid phosphatase, several protease inhibitors and calcium which are organically bound and remain stable in the $\mathrm{pH}$ range 2 to 9 [13].

Research on the antibacterial effectiveness test of pineapple pulp juice (Ananas comosus (L) has been carried out on bacteria Klebsiella pneumoniae and from the results of this study, it was found that the average diameter of the inhibition zone of pineapple flesh juice was $100 \%, 50 \%, 25 \%$, respectively. also $1.76 \mathrm{~mm}, 1.12 \mathrm{~mm}$, and $0.67 \mathrm{~mm}$, and these results indicate that the juice of pineapple flesh has a potential antibacterial effect against Klebsiella pneumoniae bacteria [6].

\section{Method}

The type of research in this research is pure laboratory experimental research in vitro, and in this research, the killing power of pineapple extract (Ananas comosus (L.)) was against Streptococcus pneumococcus with various concentrations of $0.5 \% ; 1 \% ; 2 \% ; 4 \% ; 8 \% ; 10 \% ; 20 \% ; 30 \%$; $40 \% ; 50 \% ; 60 \% ; 70 \% ; 80 \% ; 90 \% ; 100 \%$. In this study, positive (Amikacin) and negative (aquadest) controls were used to observe the growth of Streptococcus pneumococcus.

The population used in this study is pineapple (Ananas comosus (L.)) which is sold in the Bandarlampung area.

The samples used in the study were taken from the population in the form of meat and humps of pineapple extracted using ethanol (maceration method). The pineapple (Ananas comosus (L.)) used is a yellow ripe pineapple. In this study, the extract of pineapple (Ananas comosus (L.)) was made and then it was made in several concentrations of $0.5 \% ; 1 \% ; 2 \% ; 4 \% ; 8 \% ; 10 \% ; 20 \% ; 30 \% ; 40 \% ; 50 \% ; 60 \%$; $70 \% ; 80 \% ; 90 \% ; 100 \%$. The repetition is done 3 times. The pineapple extract was made in the Biochemistry Laboratory of Faculty of Math and Science Lampung University.

The data in this study will be collected by testing the killing power of pineapple extract (Ananas comosus (L.)) against Streptococcus pneumococcus at various concentrations of $0.5 \%$; $1 \% ; 2 \% ; 4 \% ; 8 \% ; 10 \% ; 20 \% ; 30 \% ; 40 \%$; 50\%; 60\%; 70\%; 80\%; 90\%; 100\%. Preparation of pineapple (Ananas comosus (L.)) extract by maceration method. The pineapple fruit is washed then peeled, then the meat and weevil are cut into pieces. The pineapple meat and hump were dried at room temperature for 5 days. The pineapple meat and humps are powdered using a blender. The powder is macerated for 24 hours using ethanol, then filtered using a Buchner funnel. The filtrate is evaporated to remove the solvent using a Rotary Evaporator to obtain the meat extract and honey pineapple humps.

The effect of pineapple meat and weevil extracts (Ananas comosus (L.)) on the growth of Streptococcus pneumococcus was determined by observing the Minimum Inhibitory Concentration (MIC) and the Minimum Bactericidal Concentration (MBC). MIC is determined by looking at the presence of solution turbidity in the test tube compared to the solution in the positive control tube and the negative control. $\mathrm{MBC}$ is determined by looking at the presence or absence of the growth of Streptococcus pneumococcus colonies on Nutrient Broth (NB) media.

All tubes were incubated at $37 \mathrm{oC}$ for 24 hours, under anaerobic conditions. Bacterial growth is seen by observing the level of clarity of the solution in each tube. The Minimal Inhibitory Level (MIC) was obtained by observing a tube that did not show any bacterial growth at the lowest concentration. Solutions that did not show germ growth were taken using sterile ose and planted on Nutrient Broth (NB) media, then incubated at $37^{\circ} \mathrm{C}$ for 24 hours under anaerobic conditions. Minimal Killing Level (KBM) is indicated by the absence of bacterial growth on Blood Agar Plate (BAP) media at the lowest concentration.

Furthermore, the inhibition test of pineapple extract was carried out against the growth of Streptococcus pneumococcus using disc blank and media Blood Agar Plate (BAP), as a control used antibiotic Amikacin $30 \mu \mathrm{g}$. Disc blank was immersed in pineapple extract at various concentrations of $0.5 \% ; 1 \% ; 2 \% ; 4 \% ; 8 \% ; 10 \% ; 20 \% ; 30 \%$; $40 \% ; 50 \% ; 60 \% ; 70 \% ; 80 \%$; 90\%; $100 \%$.

Furthermore, the disc is placed into the medium Blood Agar Plate (BAP) which has been inoculated wit hbacteria Streptococcus pneumococcus and incubated in an incubator at $370 \mathrm{C}$ for 24 hours, in an anaerobic atmosphere, and then observed the inhibition zone around the disc blank which has been soaked in pineapple extract. The experiment was repeated three times.

The collected data were processed using univariate 
analysis. Univariate analysis was carried out to determine the minimum concentration of pineapple extract which can inhibit and kill germs Streptococcus pneumococcus.

Research data on the effectiveness of the antibacterial power of pineapple meat and hump extract (Ananas comosus (L.)) on the growth of Streptococcus pneumococcus was analyzed using the Anova statistical test.

This research has obtained ethical clearance from the Health Research Ethics Commission of the Polytechnic of the Ministry of Health of Tanjung Karang Number: 174 / EC /

\section{KEP-TJK // VI / 2018.}

\section{Results}

The bromelain enzyme activity test in pineapple and honey pineapple extracts was carried out at the Laboratory of Biochemistry, Faculty of Math and Science Lampung University, the results of the bromelain enzyme activity test in pineapple and honey pineapple extracts were as follows:

Table 1. Activity of Bromelin Enzyme in Pineapple.

\begin{tabular}{llll}
\hline Name of Sample & Enzyme Activity (unit/mL) & Protein (mg/mL) & Specific Activity (unit/mg) \\
\hline Pineapple & 22.1933 & 8359 & 0.002655 \\
\hline
\end{tabular}

Table 1 shows that the bromelain enzyme activity in pineapple is 22.1933 units $/ \mathrm{mL}$, protein content is 8359 $\mathrm{mg} / \mathrm{mL}$, and the specific activity iss $0.002655 \mathrm{units} / \mathrm{mg}$.

Table 2. Results of MBC and MIC Pineapple Extract on Germs Streptococcus pneumococcus.

\begin{tabular}{llll}
\hline \multirow{2}{*}{ No. } & $\begin{array}{l}\text { Concentration } \\
(\%)\end{array}$ & Growth ofGerms & \\
\cline { 3 - 4 } & $\mathbf{( \% )}$ & MBC & MIC \\
\hline 1 & 0,5 & Positive & Positive \\
2 & 1 & Positive & Positive \\
3 & 2 & Positive & Positive \\
4 & 4 & Positive & Positive \\
5 & 8 & Negative & Negative \\
6 & 10 & Negative & Negative \\
7 & 20 & Negative & Negative \\
8 & 30 & Negative & Negative \\
9 & 40 & Negative & Negative \\
10 & 50 & Negative & Negative \\
11 & 60 & Negative & Negative \\
12 & 70 & Negative & Negative \\
13 & 80 & Negative & Negative \\
14 & 90 & Negative & Negative \\
15 & 100 & Negative & Negative \\
\hline
\end{tabular}

Table 3. Diameter of pineapple extract inhibition zone against the growth of bacteria Streptococcus pneumococcus.

\begin{tabular}{|c|c|c|c|c|c|}
\hline \multirow{2}{*}{$\begin{array}{l}\text { Concent } \\
\text { ration } \\
(\%)\end{array}$} & \multicolumn{3}{|c|}{$\begin{array}{l}\text { Diameter of inhibition zone on } \\
\text { each replicate }(\mathrm{mm})\end{array}$} & \multirow{2}{*}{$\begin{array}{l}\text { Amount } \\
(\mathrm{mm})\end{array}$} & \multirow{2}{*}{$\begin{array}{l}\text { Average } \\
(\mathrm{mm})\end{array}$} \\
\hline & I & II & III & & \\
\hline 0,5 & 0 & 0 & 0 & 0 & 0 \\
\hline 1 & 0 & 0 & 0 & 0 & 0 \\
\hline 2 & 0 & 0 & 0 & 0 & 0 \\
\hline 4 & 0 & 0 & 0 & 0 & 0 \\
\hline 8 & 0 & 0 & 0 & 0 & 0 \\
\hline 10 & 7.1 & 7.25 & 7.55 & 30.79 & 10.26 \\
\hline 20 & 11.2 & 11.3 & 11.4 & 31.77 & 10.59 \\
\hline 30 & 11.6 & 11.9 & 11.8 & 35.3 & 11.77 \\
\hline 40 & 13.20 & 13.35 & 13.42 & 39.97 & 13.32 \\
\hline 50 & 13.56 & 13.65 & 13.75 & 40.96 & 13.65 \\
\hline 60 & 13.80 & 13.85 & 13.92 & 41.57 & 13.86 \\
\hline 70 & 15.50 & 15.75 & 15.83 & 47.08 & 15.69 \\
\hline 80 & 16.30 & 16.45 & 17.02 & 49.77 & 16.59 \\
\hline 90 & 17.23 & 17.55 & 17.25 & 52.03 & 17.34 \\
\hline 100 & 20.10 & 20.34 & 21.46 & 61.90 & 20.63 \\
\hline $\mathrm{C}(+)$ & 11.89 & 11.89 & 11.89 & 35.67 & 11.89 \\
\hline C (-) & 0 & 0 & 0 & 0 & 0 \\
\hline
\end{tabular}

Ket: Control $(+)=$ Amikacin $30 \mu \mathrm{g}$

Control (-) $=$ Sterile Aquadest
In table 2 it appears that in the pineapple extract from a concentration of $8 \%$ to $100 \%$ there is no longer germ growth.

After the data normality test was carried out, the results showed that some of the data had a normal distribution (concentration $10 \%-100 \%$ ), while at a concentration of $0.5 \%$ - $8 \%$ the data distribution could not be tested. The results of the homogeneity test showed that the Levene test $p$-value $<0.05$, meaning that the data was not homogeneous. Because the Anova test conditions were not fulfilled, the hypothesis testing was carried out using the Kruskal Wallis test.

The Kruskal Wallis test results $p$-value $<0.05$, so it can be concluded that there is a difference in the mean inhibitory power in significant at least 2 treatment groups.

To determine the differences between treatment groups, atest is necessary Mann Whitney. However, because the number of samples examined in each group is only 3 , the test Mann Whitney cannot be used. Therefore, to determine the difference, the Anova test results are still used.

In line with the results of the Kruskal Wallis test, the Anova test results also showed a $p$-value $<0.05$, so it can be concluded that there is a significant difference in mean in at least 2 treatment groups. Therefore, the test was continued with post hoc LSD.

Based on the results of the post hoc LSD test, it is known that pineapple extract at a concentration of $30 \%$, has an average inhibitory power that is not significantly different from amikacin $30 \mu \mathrm{g}$. This means that only $30 \%$ pineapple extract can inhibit the Streptococcus pneumococcus bacteria with the same effectiveness as $30 \mu \mathrm{g}$ amikacin. The test results also showed that the higher the dose given, the pineapple extract's inhibition against Streptococcus pneumococcus also increased. At doses above 30\%, the mean inhibition of the extract against bacteria was significantly higher when compared to $30 \mu \mathrm{g}$ of amikacin. Pineapple extract with a concentration of $100 \%$, had the highest inhibition power significantly against bacteria Streptococcus pneumococcus.

\section{Discussion}

The results of the research that have been done show that the extracted pineapple has the ability to inhibit the growth of 
Streptococcus pneumococcus with various concentrations. In the dilution method both MIC and MBC did not find any germ growth at a concentration of $8 \%$ to $100 \%$. The results of the study also showed that the pineapple extract with a concentration of $30 \%$, had an average inhibitory power that was not significantly different from amikacin $30 \mu \mathrm{g}$. This means that only $30 \%$ pineapple extract can inhibit the Streptococcus pneumococcus bacteria with the same effectiveness as $30 \mu \mathrm{g}$ amikacin. At doses above $30 \%$, the mean inhibition of the extract against bacteria was significantly higher when compared to $30 \mu \mathrm{g}$ of amikacin. Pineapple extract with a concentration of $100 \%$, had the highest inhibition power significantly against Streptococcus pneumococcus bacteria.

The results of this study are in accordance with research conducted by Juariah and Rizki in 2018 concerning the inhibition test of Klebsiella pneumonia using pineapple peel extract (Ananas comosus 1. Merr) which states that pineapple peel extract can inhibit the growth of Klebsiella pneumoniae which is indicated by the formation of an inhibition zone. At a concentration of $7.5 \%$ an inhibition zone of $7.3 \mathrm{~mm}$ was formed and at a concentration of $10 \%$ a zone of $1.9 \mathrm{~mm}$ was formed. This shows that pineapple skin extract can be used to inhibit bacteria Klebsiella pneumonia. The large diameter of the inhibition zone of pineapple peel extract in Klebsiella pneumonia bacteria is caused by the presence of tannin, flavonoid, steroid, and triterpenoid compounds which are thought to have antibacterial effects against $K$. pneumonia [6].

The results of research conducted by Sendi Marsela, et al. In 2015, on the effect of consuming pineapple (Ananas comosus L. Merr) and pears (Pyrusbretschneideri) on the number of colonies of Streptococcus sp. in the saliva of children aged 10-12 years, which states that consuming pineapples and pears can reduce the number of bacterial colonies from the Streptococcus sp. And in this study there was a significant difference in the number of colonies of Streptococcus sp. between before and after consuming pineapples and pears in children aged 10-12 years. Pineapple fruit is one of the fruits that has antibacterial content and contains chlorine, iodine, and phenol in pineapple that can kill bacteria. When chlorine reacts with water it will form a bactericidal and iodine which is one of the strongest bactericidal substances, works quickly and almost all pathogenic germs are killed. Iodine is believed to coagulate protein. Phenol is also an antiseptic with bacterial properties, which works by denaturing bacterial cell proteins [7].

Another study conducted by Miranda on testing the antibacterial effect of feeling water from pineapple pulp against Klebsiella pneumoniae, stated that juice of pineapple pulp has potential antibacterial effects against bacteria Klebsiella pneumonia [6]. The results showed that bromelain enzyme activity in pineapples was 0.002655 units / $\mathrm{mg}$. Bromelain enzymes break down proteins by breaking peptide bonds and producing simpler proteins. Bromelin is a type of protease enzyme sulfhydryl that is able to hydrolyze peptide bonds in proteins or polypeptides into smaller molecules, namely amino acids. Bromelin is in the form of amory powder with a clear white to yellowish color, has a distinctive odor, is partially soluble in acetone, ether, and $\mathrm{CHCl} 3$. Bromelain enzyme is present in all pineapple plant tissues. About half of the protein in pineapples contains the protease bromelain. Among various types of fruit, pineapple is a source of protease with high concentrations in ripe fruit [2] demonstrates, in vitro and in vivo, anti edemateous, antiinflammatory. The role of proteolytic enzymes for therapeutic use Bromelain is included in the proteolytic enzyme group that is used as a drug for the oral systemic treatment of inflammatory, blood clotting and malignant diseases [8]. The bromelain enzyme in pineapple will later break the peptide bonds in the protein contained in the Streptococcus pneumococcus bacteria so that the germs are inhibited and killed in their growth.

The results of research conducted by Putri and Anita [11] regarding the anti-inflammatory effect of the pineapple bromelain enzyme on osteoarthritis, state that the bromelain enzyme in pineapple has proven to be effective as an antiinflammatory and analgesic for osteoarthritis sufferers. And some available evidence suggests bromelain is well absorbed orally with its therapeutic effect even enhanced in a dosedependent manner and has been shown to be a safe and effective dietary supplement [13].

Bromelain enzyme is present in all pineapple plant tissues. Bromelain enzymes are able to inhibit a type of protease enzyme that is able to hydrolyze peptide bonds in proteins into smaller molecules, namely amino acids so that they are easily digested by the body and about half of the protein in pineapples contains bromelain protease [15]. Among the various types of fruit, pineapple is a fruit with a high concentration of protease in ripe fruit. Bromelain enzymes can be extracted from the stem to the pineapple. The enzyme content is more in the pulp, this is indicated by its higher activity compared to the activity on the stem. Bromelin is isolated from pineapple by crushing the pulp to obtain a crude extract of the bromelain enzyme [10].

Bromelin can be obtained from pineapple plants either from stalks, skins, leaves, fruit, or stems in different amounts. It was reported that the enzyme content of bromelain is more in the stems which have been underutilized. The distribution of bromelin on pineapple stems is uneven and depends on the age of the plant. Bromelin content in tissues that are not old, especially those that are gummy, are very little or sometimes none at all. Meanwhile, the center of the stem contains more bromelain than the edges [3].

Many varieties of pineapple (Pineapple, Ananas comosus L.) belong to the family bromeliaseae and contain a proteolytic enzyme called bromelain. This enzyme breaks down proteins by breaking peptide bonds and producing simpler proteins [16].

The enzyme isolation was carried out by the extraction method. The purpose of this extraction series is to remove enzymes from the cells of the pineapple tissue. It should be noted that in order to obtain enzymes with good performance / activity, the materials / sources must be selected that meet the requirements. During the process, the temperature is maintained so that it does not exceed $10 \mathrm{oC}$ and it is 
necessary to add a buffer solution with a $\mathrm{pH}$ of 7.5 during blending which is a physical extraction. After that, centrifugation is carried out to separate crude enzymes from the remains of pineapple tissue. The result of centrifugation will obtain sediment, namely the remains of pineapple tissue and the supernatant is a crude enzyme bromelain. Crude extract generally has low activity because this enzyme is still a mixture of several enzymes and may still contain compounds that are not enzymes [16].

The ability of pineapple extract at a concentration of 50\% in inhibiting the growth of Streptococcus pneumococcus with the inhibition zone diameter is comparable to the antibiotics used as control, this shows that pineapple extract with a concentration of 50\% is effective in inhibiting Streptococcus pneumococcus.

The effectiveness of pineapple extract is due to the presence of the bromelain enzyme in pineapples, namely 0.002655 units / mg. This bromelain enzyme will hydrolyze the peptide bonds in proteins or polypeptides into smaller molecules, namely amino acids.

\section{Conclusion}

Pineapple (extract Ananascomosus (L.)) has the ability to inhibit the growth ofbacteria Streptococcus pneumococcus. The results of the test analysis One-way Anova obtained $p$ value $=0.000$ so that the $p$-value $<0.05$, which means that the pineapple extract concentration tested had an effect on the growth of bacteria Streptococcus pneumococcus and the results of the Least Significant Difference (BNT) or Post hoc LSD (Least Significance Different) ( $p$-value $<0.05)$ shows that pineapple extract is effective in inhibiting and killing germs Streptococcus pneumococcus at a concentration of $8 \%$. In this study, it is suggested that further in vivo studies be carried out for clinical trials. And then it is suggested to do further research using specimens from people with URI.

\section{References}

[1] DepartemenKesehatan RI. (2008). Pedoman program pemberantasan penyakit infeksi saluran pernafasan akut untuk penanggulangan premonia pada balita. Jakarta: Departemen Kesehatan RI.

[2] Donald, K. T. (1997). Fruit and vegetabel JuiceProcessing Technology. 2nd, The AUI publising, p. 180.

[3] Herdyastuti, N. (2006). Isolasi dan karakterisasi ekstrak kasar enzim bromelin dari batang nanas (Ananas comusus L. merr). Journal of Biological Researches, 12 (1), 75-77. https://doi.org/10.23869/bphjbr.12.1.200613

[4] Kim, G. L., Seon, S. H., \& Rhee, D. K. (2017a). Pneumonia and Streptococcus pneumoniae vaccine. Archives of
Pharmacal Research, $40 \quad$ (8), 885-893. https://doi.org/10.1007/s12272-017-0933-y.

[5] Kurniawan, J., Erly, E., \& Semiarty, R. (2015). Pola Kepekaan Bakteri Penyebab Pneumonia terhadap Antibiotika di Laboratorium Mikrobiologi RSUP Dr. M. Djamil Padang Periode Januari sampai Desember 2011. Jurnal Kesehatan Andalas, 4 (2), 562-566. https://doi.org/10.25077/jka.v4i2.300.

[6] Makalew, M. A. J., Nangoy, E., \& Wowor, P. M. (2016). Uji Efek Antibakteri Air Perasan Daging Buah Nanas (Ananas Comosus (L) Merr) Terhadap Bakteri Klebsiella Pneumoniae. Jurnal E-Biomedik, 4 https://doi.org/10.35790/ebm.4.1.2016.11287.

[7] Marsela, S., Probosari, N., \& Setyorini, D. (2015). Pengaruh Mengonsumsi Buah Nanas (Ananas comosus L. Merr) dan Buah Pir (Pyrus bretschneideri) terhadap Jumlah Koloni Streptococcus sp. dalam Saliva AnakUsia10-12 Tahun. STOMATOGNATIC, Jurnal Kedokteran Gigi, 12 (1), 11-15.

[8] Maurer, H. R. (2001). Bromelain: Biochemistry, pharmacology and medical use. Cellular and Molecular Life $\begin{array}{llll}\text { Sciences, } & 58 & \text { (9), } & \text { 1234-1245. }\end{array}$ https://doi.org/10.1007/PL00000936.

[9] Muhammad, Z. A. (2017). Penggunaanterapeutikdariekstrak nanas bromelaindalamperawatanbedah - Review. 67, 121-125.

[10] Purwaningsih, I. (2017). Potensi Enzim Bromelin Sari Buah Nanas (Ananas comosus 1.) Dalam Meningkatkan Kadar Protein Pada Tahu. Jurnal Teknologi Laboratorium, 6 (1), 39-46.

[11] Putri, A. B., \& Anita, A. (2017). Efek Anti InflamasiEnzimBromelin Nanas TerhadapOsteoartritis. Jurnal Kesehatan, 8 (3), 489-500.

[12] Sutarno, M., \& Liana Ayu Putri, N. (2019). Faktor-Faktor Yang Berhubungan Dengan Kejadian ISPA. JurnalAntaraKeperawatan, 2 (2), 44-50. http://scholar.google.com/scholar_url?url=http $\% 3 \mathrm{~A} \% 2 \mathrm{~F} \% 2 \mathrm{Fo}$ js.abdinusantara.ac.id\%2Findex.php\%2Fantaraperawat $\% 2$ Fart icle $\% 2$ Fdownload $\% 2$ F $76 \% 2$ F $71 \&$ hl=en\&sa $=$ T\&oi $=$ qabsggp\&ct=res\&cd $=0 \& d=16857791305498815282 \&$ ei $=\mathrm{eJ} l b X r D$ ABJKjywSXq5LIDA\&scisig=AAGBfm0AyathJQ7kX5uQJmVxk.

[13] Tochi, B. N., Wang, Z., Ying, S., Zhang, W., Ilmu, D., \& Ilmu, S. (2008). Aplikasi Terapi Protease Nanas (Bromelain): Review. 7 (4), 513-520.

[14] Weiser, J. N., Ferreira, D. M., \& Paton, J. C. (2018). Streptococcus pneumoniae: Transmission, colonization and invasion. Nature Reviews Microbiology, 16 (6), 355-367. https://doi.org/10.1038/s41579-018-0001-8

[15] Winastia, B. (2011). Analisa Asam Amino pada Enzim Bromelin dalam Buah Nanas. (Ananas Comusus) Menggunkan Spektrofotometer. [Tugas Akhir]. Semarang: Program Studi Diploma III Teknik Kimia, Fakultas Teknik Universitas Diponegoro.

[16] Wuryanti. (2004). Isolasi dan Penentuan Aktivitas Spesifik Enzim Bromelin dari Buah Nanas (Ananas comusus L.). J. Kim. Sains \& Apl. Vol. VII. No. 3, Semarang. 